\title{
Culture-led regeneration for urban spaces: Monitoring complex values networks in action
}

\begin{abstract}
According to the current European conditions, culture-led urban regeneration policies and practices are being enhanced by the introduction of interdisciplinary innovative approaches. These involve the development of methodologies and tools that are able to address material and immaterial networks of microcommunities in a systemic and circular manner of thinking among cultures, economies, and processes. When talking about overturning hierarchies and power relations and creating the conditions that are necessary to encourage a new collaborative cultural regeneration of urban public spaces and places, some open questions can be relevant: What kind of cultural resources do we have to optimize for achieving local sustainable development in response to global challenges? What kinds of new uses for public spaces and places must we improve in order to generate complex values and enhance the engagement of communities? How could communities activate themselves for building complex values networks? In order to understand how positive initiatives are activated as a "chain reaction" and facing unsolved conflicts and building new productive values systems tailor-made for a specific context are made possible, the present paper explores the components of new forms of local complex values networks in regeneration processes, based upon the ex-post evaluation of some selected Italian practices with the multi-criteria method PROMETHEE-GAIA.
\end{abstract}

Keywords: culture-led regeneration, complex values networks, public space, micro-communities, multicriteria ex-post evaluation

\section{Introduction}

In the age of global development, it is clear that urbanization is spatially and socially contradictory and conflicting (Corboz, 1998; Secchi, 2000; Brenner, 2014). Therefore, the ultimate aim of urban disciplines is to integrate natural, societal, and economic aspects through creative and adaptive processes (McHarg, 1969; Corner, 2006). McHarg (2007: 24) argues that creative fitting concerns either a social or a natural system. Consequently, the creative process is "the ability to find of all environments the most fit, and to adapt that environment and oneself'. As such, cultural processes and values systems have become focal points when it comes to debating urban regeneration as a creative and a complex reaction to controversial environments. Contrary to the arguments of globalization and capitalism, the necessity of tackling their large-scale crises has pointed out that local transitions towards sustainable patterns and flexible models of development are key activators of urban and economic upgrowth. Significantly, since the last decades of the twentieth century, in many European cities, culture has emerged as the main driver of this activation (Bianchini, 1993). As McCarthy (1998) underlines, the synergy between culture and urban regeneration constitutes a multifaceted issue, thus it has nurtured a profuse discussion around the necessary objectives and instruments of a culture-led regeneration (Evans \& Shaw, 2004; Garcìa, 2005; Miles \& Paddison, 2005). When Garcìa (2004) and McCarthy (2006) investigate the effects of prominent culture-led experiences, 
respectively in the context of the European City/Capital of Culture programme and the cultural quarters, certain controversies are nonetheless outlined. Despite undoubtedly successful, argue the authors, the adopted models reveal various externalities such as gentrification and ephemeral links with the smaller scale and its intrinsic complexity.

In this respect, five issues appear to be crucial when it comes to interpreting the potentials of local contexts in regional as well as global settings. The first point examines the concepts of space and place as distinct but connected entities. In comparing the ideas of Lefebvre and Lynch regarding the critical thinking on production and waste of spaces, Neuman (1992: 158) underlines that "[b]oth posit culture as fundamental to urban processes". Space is the measurable container of places (Lefebvre, 1970) inhabited and overlaid across history by societies and their cultural systems (Manzini, 2017).Thus, identity and culture of places (Zamagni, 2017) are the primary assets that communities claim to reaffirm and remodel in rapidly changing contexts.

The second point addresses culture in the 21st-century economies and societies. Culture relates to a set of meanings, symbols, values, ideas, organizational rules of a society that are reflected in the way that it shapes the institutions, uses the environment and nature, regulates human relations (Fusco Girard \& Nijkamp, 1997). Upon analysing the industrial decay, it is evident that Western societies have restructured the basis and actors of the economic production, thereby implying several effects on the urban spaces and the sociocultural processes (Madanipour, 2011). Since wealth and well-being no longer rely on the manufacturing of goods, other factors, such as sharing and knowledge transfer (enhanced by digital technology), have arisen as culturally-shaped channels through which creativity produces interconnected values.

The third point concerns a new approach, whereby production and consumption become part of a unique social system, "societing" (Fabris, 2008). This is a new form of contemporary marketing, which is attentive to the dynamics of society. The market is an integral part of society: a sphere where tangible and intangible relations meet. In this domain, we can count emerging economies related to eco-innovation, culture, and creativity that reflect new types of cooperation and responsibilities. This implies that competition mainly relies on the social, technological and governmental infrastructures that territories can provide in support of culture-led regeneration (Zamagni, 2017).

The fourth point considers culture, social entrepreneurship, and urban regeneration as the strategic priorities of institutional policies. Since 2010, the new economic strategies of Europe, from the Lisbon Strategy to the well-known "Horizon 2020", have aimed to achieve three shared goals: smart growth (based on skills, research, and innovation), sustainable growth (linked to the environment and sustainable development), and solidarity growth (for increasing employment and training towards better economic, social, and territorial cohesion). Within these three objectives, Europe is boosting national and local governmental bodies, thereby enhancing territorial responsiveness and cultural competitiveness by promoting multi-sectorial and multi-actor networks.

The fifth and final point illuminates the repertoire of creative practices led by the civic society and the third sector for achieving regeneration processes. In declined areas, these practices sometimes originate as smaller scale tactics to create temporary community places (e.g. tactical urbanism approaches and tools). Indeed, this approach involves the combining of a site-specific "adaptive re-cycle" (Gasparrini \& Terracciano 2016; Sposito, 
2016) with the empowerment of the social and cultural values that are locally embedded. At other times, these practices derive from Cultural and Creative Industries (CCIs) or cultural districts (Sacco \& Pedrini, 2003). To put it simply, these are companies or clusters of companies which re-use deprived areas and abandoned buildings to operate creative economies by generating knowledge and benefitting from the intellectual property, in particular through cognitive abilities, capacity building, and community engagement (Ufficio Studi Federculture, 2013; Community places, 2014). Moreover, it is true that, in all its nuances, this repertoire challenges the traditional hierarchies built in the planning and decision-making processes, thereby creating conditions for encouraging new hybrid models of public-private partnerships (Micelli, 2009). Yet, the fact remains that, on the one hand, policy and governance models rarely capture the heterogeneity that distinguishes the local creative scenes. On the other hand, the chart of creative practices only partially makes the difference in triggering the processes of urban regeneration. Indeed, it is common that the practices dissipate the efforts and thus weaken the outputs and jeopardize the opportunities of being engaged in wider cultural, social, and economic arenas.

Against the depicted background, this paper elaborates on the hypothesis that creative practices linking culture and urban regeneration should place particular emphasis on:

- Generating complex values of places;

- Building complex values networks.

The former helps to integrate and balance the various dimensions of value (spatial, economic, social, environmental, etc.), making value a complex output of culture-led regeneration. The latter put the complex value in action through the means of networks that increase and redefine it through "chain-reactions" among culture, economies, and processes, strengthening their related ties. As such, culture-led urban regeneration is investigated as a driver of complex values networks tailor-made for a specific local context. Indeed, "thinking through complex values implies the inclusion of a multidimensional perspective, taking into account tangible and intangible values, hard and soft values, objective and subjective values, use values, non-use values and intrinsic values, and their synergic and complementary relationships" (Cerreta, 2010: 382). The central questions that motivate this paper are indeed the following: What kind of cultural resources do we have to optimize for achieving local sustainable development in response to global challenges, especially in controversial contexts? What kinds of new uses must we improve in order to generate complex values and enhance the engagement of communities? How could communities activate themselves for building complex values networks? The present paper attempts to respond to these research questions, and it is structured in the following manner: the first part (Section 2) proposes a methodological and data collection approach, which links culture, economies, and creative processes for urban regeneration; the second section (Section 3) explains an ex-post evaluation of certain cultural creative experiences in Southern Italy, applying the multi-criteria method PROMETHEE-GAIA for analysing results from different perspectives and finding a balanced decisions system that considers the role of each criterion; the third section (Section 4) presents a discussion on the entire process and highlights conclusions (Section 5) while putting forth follow-up points related to the research inputs. 


\section{Culture, economies, and creative processes for urban regeneration}

In recent times, the industrial/urban system has had significant negative impacts in terms of economic and social inequalities. This is due to technological and IT revolutions as well as the implementations of new financial models that are not always oriented towards local sustainable development (Napolitano, 2016). The main problems encountered relate to the lack of a systemic approach to territorial productivity in the process of community development. The production should be oriented towards the enhancement of the local context, and it should cater to the people's specific needs, interests, and abilities to network and build new relationships. As such, production cannot be focused on a single market, but it should be able to respond to the territorial complexity of resources (Cerreta \& Daldanise, 2017), thereby supporting long-term sustainable development.

The cultural creative enterprise (Solima, 2005; Bosi, 2017), with its multidisciplinary nature, is designed for the exchange of knowledge; indeed, it represents one of the first experimental alternatives to "traditional" industrial development. It stimulates the growth of many sectors, as evidenced by research reports produced by several governmental agencies, which had important effects on development models and the economy in general. In 2003, the turnover in Europe's creative and cultural sector stood at around 654 billion euros, representing 2.6\% of the European Gross Domestic Product (GDP). In the same year, while the nominal growth of the European economy was $17.5 \%$, the cultural and creative sector grew by $12.3 \%$, contributing $19.7 \%$ to the overall economic growth in Europe (Napolitano, 2016). In 2016, the cultural and creative sector in Italy produced an added value of nearly 90 billion euros (approximately 1.6 billion euros more than the previous year, and $6.0 \%$ of the total wealth produced in the country). It is worth noting that the major investments come from the private component, prevalent in all activities, and then from public institutions for valorizing and preserving historical and artistic heritage. In addition, investments also come from non-profit organizations, mainly present in performing and visual arts (Unioncamere \& Fondazione Symbola, 2017). However, disadvantaged or peripheral territories are particularly noteworthy areas of unsolved conflicts (Esposito de Vita \& Ragozino, 2014), which require a governance system tailor-made for the local context and for the creative/cultural industries within.

In the South of Italy, some disadvantaged areas, despite criticism, offer fertile ground for developing new cultural approaches for learning and sharing instruments. The main conflicts relate to unemployment, industrial abandoned areas, deprived historical centres, different interests of the public and the private, and inclusion of foreign citizens, etc. With the aim of countering these kinds of conflicts, "creative capital" (Florida, 2003) is considered to be a key element for attracting and implementing a new workforce and innovative forms of experimentation on multicultural identities, knowledge economies, and innovation cultures. Creative capital is able to optimize local cultural resources for rebuilding relationships among communities, values, and public spaces (Forester, 1997; Scott, 2000; Fusco Girard, 2010; Sassen, 2011; Bertacchini et al., 2012; CHCfE, 2015) in a productive way, thereby enhancing culture-led urban regeneration processes that are locally-embedded.

From this perspective, the methodological approach, as elaborated in Figure 1, aims to find out which new sustainable uses in a space are able to stimulate this creative capital and build networks of micro-communities as socio-cultural places. These considerations are strictly linked to new forms of welfare that consider the proximity of services, 
activities and places (Boschma, 2005) as an opportunity of regeneration in a wide chain of micro-networks. By attempting to respond to the research questions that have been highlighted in the introduction, and by starting from the local cultural values and the changing uses of urban spaces, this study explores if creative practices are able to:

1. Optimize tangible/intangible cultural resources for local sustainable development;

2. Generate values and enhance the engagement of communities through new sustainable uses;

3. Build capillary complex networks among people, values, and spaces.

Starting from these objectives, the methodological approach aims to build a virtuous relationship among the local culture, which captures the territorial pulse, and the process for stimulating creative capital together with the economy for implementing productive clusters.

\section{Methodology}

The methodological approach (Figure 1) explores the synergy between culture and urban regeneration, underlying that it can be effective if it is able to provide a common framework which brings together the different issues (economic, social, and environmental). In the cooperative process of social and urban re-weaving, culture becomes an enabler and an autopoietic tool, which is able to become a link between the different components of urban life, key problem-solving strategies, and local communities directly involved in the identification and implementation of change (Brigato et al., 2014; Torre et al., 2016).

The whole approach of this study is structured as an ex-post evaluation process of three creative practices of regeneration processes in Southern Italy that have been selected for understanding how to build micro-communities and complex values networks in public spaces (Cerreta, 2010). By definition, ex-post evaluation is interpreted as an objective and systematic assessment of an ongoing or completed project, practice, programme or policy, its design, implementation, and results (Samset, 2003; OECD, 2002). The ex-post evaluation approach is comprehensive, and it relates to many types of assessments, from socio-economic to business-value, and from holistic to performance measurement (Olsson et al., 2010). Some examples include:

- Ex-post recalculations of ex-ante cost-benefit analyses;

- Evaluations based on the principles of corporate finance;

- Multi-criteria evaluations.

The analysis considers three domains as the major aspects of the cultural, social, and economic vitality of cities, elaborated from a new tool for monitoring the performance of cultural and creative cities adopted in Europe, with both quantitative and qualitative data (European Commission, 2017):

1. Cultural Vibrancy (CV) for capturing elements of the cities' "cultural pulse";

2. Creative Economy (CE) in terms of creative sector opportunities, cultural innovation, and knowledge-based jobs;

3. Enabling Environment (EE) for stimulating creative capital and engagement in tangible/intangible heritage regeneration. 


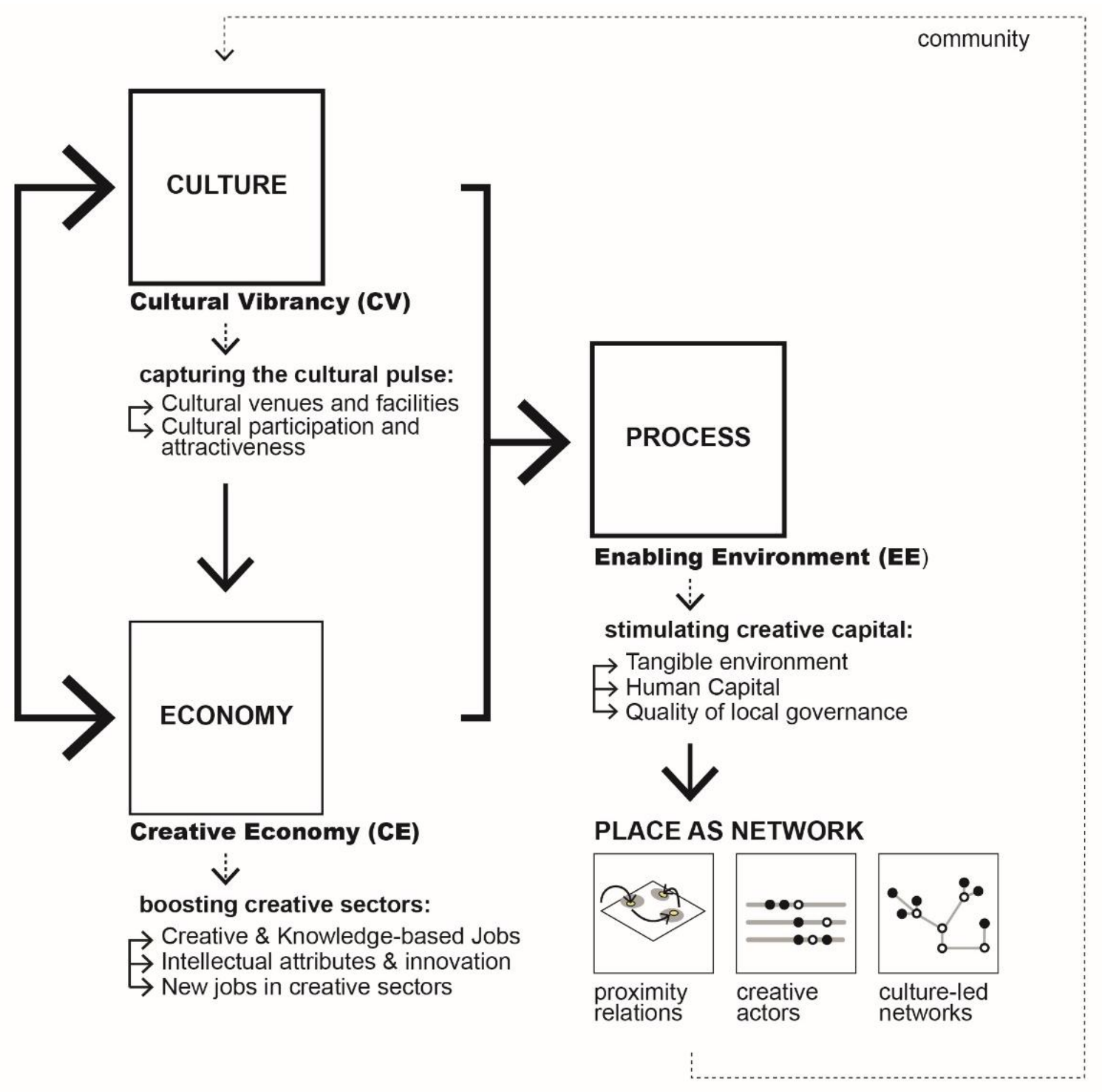

Figure 1: Methodological approach (illustration: authors; source: European Commission, 2017).

The nine dimensions of Cultural and creative cities monitor (European Commission, 2017) in this paper are modified in order to achieve the three main research objectives that are described above; the ultimate goal is to achieve a culture-led (Miles \& Paddison, 2005; Sacco, Ferilli \& Blessi, 2014) urban regeneration that is locally-embedded. We employed a diverse scale of analysis, rather than the metropolitan range that is used with the European tool, and focus on a municipal or district scale linked to proximity and local welfare. The evaluation framework considers the European Union's Cultural and Creative Cities Monitor as a reference framework. On the one hand, the Monitor's domains and dimensions are representative of describing creativity. However, on the other hand, its criteria and indicators are not adequate to reveal the peculiarities, efficacy, and impacts of singular local practices. In light of this observation, the reference framework has been adapted to describe local features and proximity issues. We argue that an appropriate evaluation framework should consider the relationships between culture, economies, and processes that are activated by the local practices on the municipal and district scale. Using this approach, we consider the domains, dimensions, criteria, and situated indicators as shown in Table 1. The relationship between these categories of domains, 
dimensions, and criteria valorizes anthropic and natural resources as a foundation for the participatory and culture-led regeneration of local public spaces and improves an "exante" evaluation framework for future practices.

Table 1: The ex-post evaluation framework: Domains, dimensions, criteria, indicators (based on: European Commission, 2017).

\begin{tabular}{|c|c|c|c|}
\hline Domains & Dimensions & Criteria & Indicators \\
\hline \multirow[t]{14}{*}{$\begin{array}{l}\text { Cultural Vibrancy } \\
(\mathrm{CV})\end{array}$} & \multirow[t]{9}{*}{$\begin{array}{l}\text { CV.1. Cultural } \\
\text { venues and } \\
\text { facilities }\end{array}$} & $\begin{array}{l}\text { CV.1.1. Virtual } \\
\text { landmarks }\end{array}$ & $\begin{array}{l}\text { I.1. Number of people who } \\
\text { report the site as a point of } \\
\text { interest }\end{array}$ \\
\hline & & \multirow[t]{2}{*}{ CV.1.2. Recovered sites } & $\begin{array}{l}\text { I.2. Number of recovered } \\
\text { properties }\end{array}$ \\
\hline & & & I.3. Surface of regeneration site \\
\hline & & \multirow[t]{4}{*}{$\begin{array}{l}\text { CV.1.3. Surrounding } \\
\text { territory }\end{array}$} & $\begin{array}{l}\text { I.4. Distance from the urban } \\
\text { centre }\end{array}$ \\
\hline & & & $\begin{array}{l}\text { I.5. Percentage of foreign } \\
\text { residents }\end{array}$ \\
\hline & & & I.6. Number of tourists \\
\hline & & & I.7. Unemployment rate \\
\hline & & \multirow[t]{2}{*}{$\begin{array}{l}\text { CV.1.4. Cultural } \\
\text { activities }\end{array}$} & $\begin{array}{l}\text { I.8. Number of cultural } \\
\text { services }\end{array}$ \\
\hline & & & I.9. Number of cultural events \\
\hline & \multirow{5}{*}{$\begin{array}{l}\text { CV.2. Cultural } \\
\text { participation and } \\
\text { attractiveness }\end{array}$} & \multirow[t]{3}{*}{$\begin{array}{l}\text { CV.2.1. Cultural } \\
\text { participants }\end{array}$} & $\begin{array}{l}\text { I. } 10 \text {. Number of participants at } \\
\text { cultural events }\end{array}$ \\
\hline & & & $\begin{array}{l}\text { I.11. Number of institutional } \\
\text { actors }\end{array}$ \\
\hline & & & $\begin{array}{l}\text { I.12. Number of non- } \\
\text { institutional actors }\end{array}$ \\
\hline & & \multirow[t]{2}{*}{$\begin{array}{l}\text { CV.2.2. Place } \\
\text { attractiveness }\end{array}$} & $\begin{array}{l}\text { I.13. Number of cultural } \\
\text { projects activated }\end{array}$ \\
\hline & & & $\begin{array}{l}\text { I.14. Number of crowdfunding } \\
\text { campaigns }\end{array}$ \\
\hline \multirow{14}{*}{$\begin{array}{l}\text { Creative } \\
\text { Economy }(\mathrm{CE})\end{array}$} & \multirow{7}{*}{$\begin{array}{l}\text { CE.1. Creative and } \\
\text { knowledge-based } \\
\text { jobs }\end{array}$} & \multirow{4}{*}{$\begin{array}{l}\text { CE.1.1. Creative } \\
\text { opportunities }\end{array}$} & I.15 Number of jobs activated \\
\hline & & & $\begin{array}{l}\text { I.16. Funds collected by } \\
\text { crowdfunding or through other } \\
\text { campaigns }\end{array}$ \\
\hline & & & $\begin{array}{l}\text { I.17. Revenues for the year } \\
\text { from the activities offered }\end{array}$ \\
\hline & & & $\begin{array}{l}\text { I.18. Private investment on the } \\
\text { project }\end{array}$ \\
\hline & & \multirow[t]{3}{*}{ CE.1.2. Network } & I.19. Number of associates \\
\hline & & & $\begin{array}{l}\text { I.20. Number of temporary } \\
\text { employees }\end{array}$ \\
\hline & & & $\begin{array}{l}\text { I.21. Number of business } \\
\text { partners/collaborations }\end{array}$ \\
\hline & \multirow{3}{*}{$\begin{array}{l}\text { CE.2. Intellectual } \\
\text { attributes and } \\
\text { innovation }\end{array}$} & \multirow[t]{2}{*}{ CE.2.1. Innovation } & I.22. Innovative format \\
\hline & & & I.23. Number of digital tools \\
\hline & & $\begin{array}{l}\text { CE.2.2. Intellectual } \\
\text { attributes }\end{array}$ & $\begin{array}{l}\text { I.24. Number of cultural } \\
\text { sectors included in the project }\end{array}$ \\
\hline & \multirow[t]{4}{*}{$\begin{array}{l}\text { CE. } 3 . \text { New jobs in } \\
\text { creative sectors }\end{array}$} & \multirow[t]{2}{*}{$\begin{array}{l}\text { CE.3.1. Jobs for young } \\
\text { people }\end{array}$} & $\begin{array}{l}\text { I. } 25 . \text { Number of enterprises for } \\
\text { young people }\end{array}$ \\
\hline & & & $\begin{array}{l}\text { I.26. Number of young people } \\
\text { involved }\end{array}$ \\
\hline & & \multirow[t]{2}{*}{$\begin{array}{l}\text { CE.3.2. Jobs in new } \\
\text { cultural creative sectors }\end{array}$} & $\begin{array}{l}\text { I.27. Number of enterprises } \\
\text { involved }\end{array}$ \\
\hline & & & $\begin{array}{l}\text { I.28. Number of people } \\
\text { employed }\end{array}$ \\
\hline
\end{tabular}




\begin{tabular}{|c|c|c|c|}
\hline \multirow[t]{11}{*}{$\begin{array}{l}\text { Enabling } \\
\text { Environment } \\
\text { (EE) }\end{array}$} & \multirow[t]{3}{*}{$\begin{array}{l}\text { EE.1. Tangible } \\
\text { environment }\end{array}$} & EE.1.1. Design solutions & $\begin{array}{l}\text { I.29. Number of eco design } \\
\text { projects } \\
\text { I.30. Number of existing plans } \\
\text { or urban regeneration projects }\end{array}$ \\
\hline & & \multirow{2}{*}{$\begin{array}{l}\text { EE.1.2. Accessibility } \\
\text { and connections }\end{array}$} & I.31. Number of infrastructures \\
\hline & & & I.32. Number of creative paths \\
\hline & \multirow[t]{6}{*}{$\begin{array}{l}\text { EE.2. Human } \\
\text { Capital }\end{array}$} & \multirow[t]{2}{*}{$\begin{array}{l}\text { EE.2.1. Education and } \\
\text { engagement }\end{array}$} & $\begin{array}{l}\text { I.33. Number of courses } \\
\text { activated }\end{array}$ \\
\hline & & & $\begin{array}{l}\text { I.34. Number of workshops for } \\
\text { the year }\end{array}$ \\
\hline & & \multirow{2}{*}{$\begin{array}{l}\text { EE.2.2. Local and } \\
\text { international } \\
\text { relationships }\end{array}$} & $\begin{array}{l}\text { I.35. Number of local } \\
\text { promoters }\end{array}$ \\
\hline & & & $\begin{array}{l}\text { I.36. Number of international } \\
\text { partners }\end{array}$ \\
\hline & & \multirow{2}{*}{$\begin{array}{l}\text { EE.2.3. Communication } \\
\text { strategy }\end{array}$} & I.37. Number of likes received \\
\hline & & & $\begin{array}{l}\text { I.38. Number of social } \\
\text { accounts }\end{array}$ \\
\hline & \multirow{2}{*}{$\begin{array}{l}\text { EE.3. Quality of } \\
\text { local governance }\end{array}$} & \multirow{2}{*}{$\begin{array}{l}\text { EE.3.1. Public funds and } \\
\text { incentives for culture }\end{array}$} & I.39. Incentives for culture \\
\hline & & & I.40. Public funds \\
\hline
\end{tabular}

In search of a balance among the three main issues (culture, economies, and processes), we selected the multi-criteria evaluation approach, which takes into account a systemic view of such a multi-dimensional problem (Roy, 1985; Munda, 1993; Proctor \& Drechsler, 2006; Ishizaka \& Nemery, 2013; Cerreta et al., 2016). Subsequently, within the ex-post evaluation framework, a core set of indicators has been identified depending on available and common data. Based on the indicators pointed above, the comparative analysis has been applied to the case studies through a multi-criteria decision support system, the PROMETHEE-GAIA method of Preference Ranking Organisation Method for Enrichment Evaluations family (Behzadian et al., 2010). The PROMETHEE method is one of the most recent Multi-Criteria Decision Analysis MCDA methods, which was developed by Brans (1982), and further extended by Vincke and Brans (1985). It is an outranking method that is used for a finite set of alternative actions to be ranked and selected among criteria that are often conflicting.

The choice of the PROMETHEE-GAIA method is linked to useful features of outranking methods, in which a disadvantage on a specific point of view could be compensated by advantages on other viewpoints (Pirlot, 1997) and finding a degree among stakeholders on the predominance of one option over another (Vincke, 1992). On the basis of several criteria defining a set of options, the method identifies the pros and cons of the alternatives, obtaining a ranking among them with a pair-wise comparison of indicators while also attributing different weights to the criteria for defining a sensitivity analysis. In particular, the GAIA plane is a descriptive tool that supports the PROMETHEE method and provides a powerful graphical representation of the results, which is useful in understanding the conflicts among criteria and in dealing with the problem of the weights related to them (Behzadian et al., 2010). The GAIA plane is the result of the Principal Component Analysis (PCA) and is based on the reduction of multi-dimensional problems to two-dimensional ones. The PCA provides a valuable tool for the decision-maker to identify the criteria, expressing similar or conflicting preferences, as well as the quality of each alternative on the different criteria. Starting from these premises, our line of work has been carried out to pursue the research objectives following these steps: 
1. Defining the main objectives and the results of practices for highlighting the kind of cultural resources optimized in a creative production for achieving local sustainable development;

2. Selecting ten indicators common to all case studies, on the basis of data recovered, within the dimensions of: Cultural venues and facilities (CV.1.), Cultural participation and attractiveness (CV.2.), Intellectual attributes and innovation (CE.2.), New jobs in creative sectors (CE.3.), Human capital (EE.2.). This common framework demonstrates the ability of these practices to generate values and enhance the stimulation of communities through new sustainable uses;

3. Evaluating the alternative practices using a multi-criteria analysis and a sensitivity analysis to underline and test the real capacity of these "creative communities" in building complex productive networks among people, values, and spaces.

According to the above steps, the ex-post evaluation framework elaborated has been useful in identifying the relations among domains, dimensions, criteria and indicators, and their relevance for the performance of each selected practice.

\section{Case studies: Ex-post evaluation of creative practices in Southern Italy}

In the South of Italy, local communities are usually seen as repositories of fundamental values and traditions, which are expressions of local potentials in various sectors (e.g. agriculture, education, art, architecture, and manufacturing). In particular, within a large framework of virtuous experiences spread across the South of Italy, the following best practices (Figure 2) have been selected for their operative attempt to build job opportunities for young people, develop micro-economies' networks for local public spaces, and improve social innovation involving different actors:

1. VàZapp'-Coltiviamo idee, Foggia, Apulia Region;

2. ExFadda - Laboratorio urbano, San Vito dei Normanni, Brindisi, Apulia Region;

3. Officine Culturali, Catania, Sicily Region.

The first example involves a digital platform and a physical headquarters in Foggia (in Apulia) where young farmers are trying to change farming methods (Internet 1): "VàZapp' - Coltiviamo idee" (VàZapp' - We cultivate ideas). The focus of the project is on reinventing the short food supply chains (SFSCs) into a cultural food supply chain, the idea of which was inspired by an Italian word game: from a supply chain "corta" (short) to another "colta" (cultural). The project aims to help people meet virtually or physically in order to share ideas and problems while building networks and businesses. VàZapp' has the goal of rethinking the classic SFSCs steps, such as packaging, logistics, and communication for selling a product to shops or directly to consumers. In fact, in a cultural food supply chain of oil, for example, the farmer produces oil, the designer studies the packaging, and the expert in communication builds a marketing strategy. Everyone brings an added value that translates into real income (Cinquemani, 2016). 


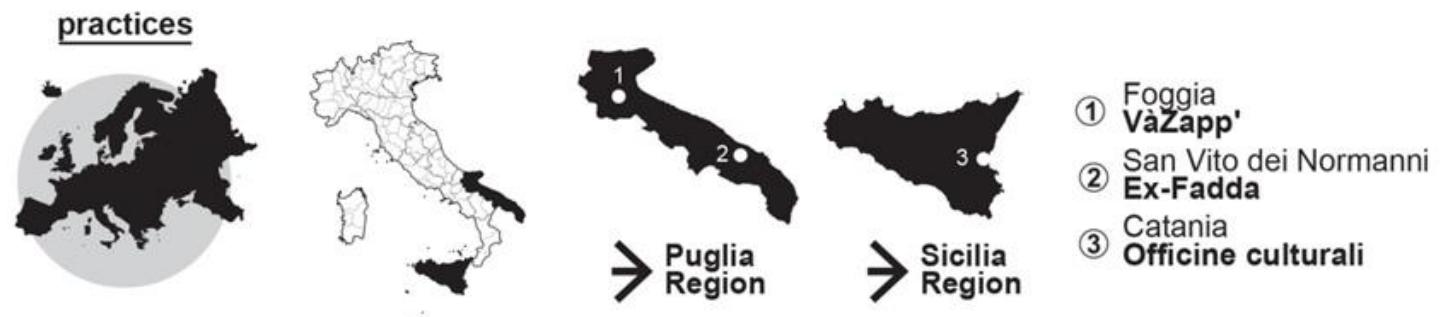

\section{public space objectives}

$$
\begin{array}{r}
\text { Puglia } \\
\text { rural ground } \\
\end{array}
$$

(1)

$\begin{array}{ll}\text { (2) } \rightarrow \begin{array}{l}\text { Ex-wine } \\ \text { industry }\end{array} & \begin{array}{l}\text { Designing a FabLab as place } \\ \text { of social innovation and } \\ \text { a knowledge factory } \\ \text { for new local economies }\end{array} \\ \rightarrow \begin{array}{l}\text { FabLab as a place of social } \\ \text { innovation and knowledge factory. } \\ \text { Sharing ideas, tools, and skills } \\ \text { to create new economies. } \\ \text { Co-working for local development. } \\ \text { Making a suburban community } \\ \text { attractive. }\end{array}\end{array}$

Benedictine Monastery compex
Networking of farmers as

a basis of new productive relationships for local employment and rural development.

Farming for local employment and development.

Joining and sharing to create a common future.

'Cultural' food supply chain to overcome isolation of young farmers.

\section{results}

Recovered rural area co-working and events spaces web platform and creative formats.

Physical sites: co-working space, 150 -seat grain amphitheatre. Virtual site: web platform (vazapp.it). Producer-consumer dialogues to generate values. Narratives of successful stories:

\#WeArelnPaglia, a grain amphitheatre Cultural projects and formats to optimise the SFSCs: \#contadinner 202020 , a project that brings 400 young farmers together. \#FuoriDallaCassetta, a motivational format for young farmers.

\#ciucciottoday, a format to support an environmentally-friendly agriculture.

\section{Recovered historic fabric} workspace/laboratory for local activities events spaces and urban regeneration

'XF Lab', a workspace for local associations. 'XF Live', a self-construction site for live events. XF Theater', for shows, congresses, and exhibitions. 'ExFadda Caffè', hosted in the previous factory keeper's house.

'La Coccinella' (The Ladybug), a recreational centre. 'The Garden' for social gardens, playgrounds, etc. 'XFoto', a site created by local young photographers. 'Arti di Strada' (Street arts) for artistic/theatre products. 'XFarmer Market', a marketplace for zero kilometre producers with the collaboration of "Coldiretti". 'Fatto a mano' (Handmade), a workshop dedicated to small handicrafts.

'XFood', a social, zero kilometre restaurant that involves 16 disabled young people. Santu Vitu Mia. Urban regeneration programme,

\section{Recovered historic building} museum of Archaeology emotional/cognitive experiences and professional services

Valorisation of the Benedictine Monastery (Catania Cultural Heritage).

Equipping the store CUB - Castello Ursino Bookshop. Museum of Archaeology, born with the Project Catania-Lecce.

Different uses and services to enjoy places of culture as emotional and cognitive formats.

Edutainment and Museum didactics.

Professional training services.

Management of uses and the valorisation of the botanical garden of Catania.

Design services.

Promotion, communication, and marketing services.

Figure 2: Creative practices localization and synthetic matrix referring to achieved objectives and results (illustration: authors, based on data retrieved from Internet 1, 2, and 3).

In the heart of the Apulia region, there is another experience of local regeneration in San Vito dei Normanni (near Brindisi): an old abandoned oenological factory (Internet 2), "Dentice di Frasso", which is being transformed into a new cultural industry for creativity and social innovation, called ExFadda. ExFadda is a multidisciplinary hybrid space where daily workers and volunteers involve themselves in the regeneration of the wine fabric 
through activities ranging from workshops, theatre, live music, playground, bar, large garden, etc. The project was promoted by the Municipality of San Vito dei Normanni and the Apulia Region, and within the "Bollenti Spiriti" youth policy. ExFadda is managed by several local realities such as Sandei s.r.l, Magazzini Teatrali Dardagnam, the associations Un Futuro a Sud, Bendicò e le Stelle, and Epifani Barbers. This organized community has developed the word "welfare" in sharing actions for professional and economic opportunities (La Redazione, 2014). In the region of Sicily, another successful experience is respresented by an association (with an operational office in the Benedictine Monastery complex in Catania): the "Officine Culturali" ("Cultural Offices"). The key idea involves the development of professionalism in the field of activities related to the management and enhancement of cultural heritage. These professional skills are oriented towards future generations in order to promote knowledge of history and place identity. The valorization strategy of cultural goods and activities is managed at every stage: from designing the project with economic and social impacts analyses on the territory to data monitoring and the dissemination of results (Internet 3).

\begin{tabular}{|c|c|c|c|c|c|c|c|c|c|c|}
\hline scenario 1 & $\underline{12}$ & $\underline{14}$ & $\underline{\mathbf{1 5}}$ & 17 & $\underline{18}$ & $\underline{113}$ & $\underline{122}$ & $\underline{126}$ & $\underline{137}$ & $\underline{138}$ \\
\hline Unit & unit & unit & unit & unit & unit & unit & unit & unit & unit & unit \\
\hline \multicolumn{11}{|l|}{ preferences } \\
\hline Min/Max & $\max$ & $\min$ & $\max$ & $\min$ & $\max$ & $\max$ & $\max$ & $\max$ & $\max$ & $\max$ \\
\hline Weight & 1.0 & 1.0 & 1.0 & 1.0 & 1.0 & 1.0 & 1.0 & 1.0 & 1.0 & 1.0 \\
\hline $\begin{array}{l}\text { Function of } \\
\text { preferences }\end{array}$ & usual & usual & usual & usual & usual & usual & usual & usual & usual & usual \\
\hline $\begin{array}{l}\text { Thresholds } \\
\text {-Q: Indifference }\end{array}$ & $\begin{array}{c}\text { abs. } \\
\mathrm{n} / \mathrm{a}\end{array}$ & $\begin{array}{l}\text { abs. } \\
\mathrm{n} / \mathrm{a}\end{array}$ & $\begin{array}{c}\text { abs. } \\
\mathrm{n} / \mathrm{a}\end{array}$ & $\begin{array}{l}\text { abs. } \\
\text { n/a }\end{array}$ & $\begin{array}{l}\text { abs. } \\
\text { n/a }\end{array}$ & $\begin{array}{l}\text { abs. } \\
\text { n/a }\end{array}$ & $\begin{array}{l}\text { abs. } \\
\mathrm{n} / \mathrm{a}\end{array}$ & $\begin{array}{l}\text { abs. } \\
\text { n/a }\end{array}$ & $\begin{array}{l}\text { abs. } \\
\text { n/a }\end{array}$ & $\begin{array}{l}\text { abs. } \\
\mathrm{n} / \mathrm{a}\end{array}$ \\
\hline$-P$ : Preference & $\mathrm{n} / \mathrm{a}$ & $\mathrm{n} / \mathrm{a}$ & $\mathrm{n} / \mathrm{a}$ & $\mathrm{n} / \mathrm{a}$ & $\mathrm{n} / \mathrm{a}$ & $\mathrm{n} / \mathrm{a}$ & $\mathrm{n} / \mathrm{a}$ & $\mathrm{n} / \mathrm{a}$ & $\mathrm{n} / \mathrm{a}$ & $\mathrm{n} / \mathrm{a}$ \\
\hline -S: Gaussian & $\mathrm{n} / \mathrm{a}$ & $\mathrm{n} / \mathrm{a}$ & $\mathrm{n} / \mathrm{a}$ & $\mathrm{n} / \mathrm{a}$ & $\mathrm{n} / \mathrm{a}$ & $\mathrm{n} / \mathrm{a}$ & $\mathrm{n} / \mathrm{a}$ & $\mathrm{n} / \mathrm{a}$ & $\mathrm{n} / \mathrm{a}$ & $\mathrm{n} / \mathrm{a}$ \\
\hline \multicolumn{11}{|l|}{ statistic } \\
\hline Minimum & 2.0 & 500 & 2.0 & 15.0 & 5.0 & 6.0 & 2.0 & 8.0 & 13316 & 5.0 \\
\hline Maximum & 3.0 & 7500 & 4.0 & 20.0 & 43.0 & 17.0 & 17.0 & 21.0 & 17302 & 6.0 \\
\hline Medium & 2.3 & 2833.3 & 3.3 & 17.0 & 20.0 & 12.7 & 7.7 & 13.3 & 15014.3 & 5.7 \\
\hline $\begin{array}{l}\text { Standard } \\
\text { deviation }\end{array}$ & 0.5 & 3299.8 & 0.9 & 2.2 & 16.2 & 4.8 & 6.6 & 5.6 & 1679.8 & 0.5 \\
\hline \multicolumn{11}{|l|}{ evaluations } \\
\hline Ex Fadda & 2.0 & 500.0 & 2.0 & 15.0 & 43.0 & 17.0 & 17.0 & 8.0 & 17302.0 & 6.0 \\
\hline 口 VàZapp' & 2.0 & 7500.0 & 4.0 & 20.0 & 5.0 & 6.0 & 4.0 & 11.0 & 14425.0 & 6.0 \\
\hline $\begin{array}{l}\text { Officine } \\
\text { Culturali }\end{array}$ & 3.0 & 500.0 & 4.0 & 16.0 & 14.0 & 15.0 & 2.0 & 21.0 & 13316.0 & 5.0 \\
\hline
\end{tabular}

Figure 3: The evaluation matrix: The PROMETHEE-GAIA Method (illustration: authors).

The aim of this analysis is to compare different typologies of realized practices in distinct surrounding contexts, thus highlighting the main objectives and the main results that have been achieved. Starting from the ex-post evaluation framework (Table 1), and based on data recovered, ten indicators were selected (I.2, I.4, I.5, I.7, I.8, I.13, I.22, I.26, I.37, I.38) that were common to all case studies. The practices, conceived as alternatives (Table 3), are assessed upon implementing the multi-criteria method PROMETHEE-GAIA, in which an outranking procedure of data aggregation is applied as the basis of evaluation (Brans \& Mareschal, 1990). 
The method is also a key negotiation tool for finding an agreement among conflicting points of view, and it helps to better understand the difficulties in making good decisions owing to the following actions:

- Visualizing decision or evaluation problems;

- Achieving consensus decisions among several decision-makers;

- Justifying or invalidating decisions starting from objective elements.

The PROMETHEE-GAIA method is based on the computation of unicriterion pair-wise preference degrees (scored between 0 and 1), which rank all the alternatives from best to worst from the point of view of the decision-maker. The pair-wise comparisons of the alternatives are based on three preference flows for consolidating the results: Phi+ $(\mathrm{f}+)$ : the positive flow; Phi- (f-): the negative flow; Phi (f): the net flow. The PROMETHEEGAIA points out how the decision-maker perceives the difference between the objective evaluations (often measured) on every criterion. The unicriterion preference degree is computed for each criterion, rescaling or enriching the evaluations of the actions by means of preference information. The pair-wise comparisons refer to the difference between the evaluations of the two actions, like the difference in price or in quantity: e.g. cardinal scale (unit) as shown in our cases study evaluation matrix (Figure 3).

In this study, we use several PROMETHEE-GAIA tools in order to evaluate the three creative practices. We also employ a sensitivity analysis, which shows the changes in different alternatives from different perspectives of the decision-makers. The variation in the values of the criteria parameters may change scores and ranking, and it is crucial for performing some tests of the stability of the final decision (Ishizaka \& Nemery, 2013).

The PROMETHEE Diamond is a two-dimensional representation of both PROMETHEE I partial and II complete rankings; each alternative is represented as a point in the (Phi+, Phi-) plane angled at $45^{\circ}$. In the PROMETHEE Network, actions are instead represented by nodes and arrows drawn from emerging preferences. Both tools can appreciate the proximity between actions and, thus, the levels of incomparability in the partial ranking (Mareschal, 2013).

The GAIA Web window tool shows a representation of the unicriterion net flow scores for the selected alternative in order to compare the profiles of every alternative with the use of a spider-web display for one action. Furthermore, the GAIA visual analysis (Figures 4 and 5) can help to analyse and better explain the decision problem, as it allows to understand the choices that are possible and the ones that are not (Mareschal, 2013). The complete ranking identifies Ex Fadda, followed by Officine Culturali and VàZapp'.

The profile of Ex Fadda practice (Figure 4a) is more relevant for the indicators I37 (Number of likes received), I38 (Number of social accounts), I4 (Distance from urban centre), and I2 (Number of recovered properties), which combine the tangible transformation with its ability to communicate on the web. The profile of Officine Culturali (Figure 4c) identifies the following relevant indicators: I4 (Distance from urban centre), I2 (Number of recovered properties), I26 (Number of young people involved), I5 (Percentage of foreign residents). The physical components and the communities-related components constitute the main characteristics of a complex process, where young people and foreign residents can be considered to be the drivers of change in values. The profile of VàZapp' (Figure 4b) describes its performance considering the following indicators: I5 (Percentage of foreign residents), I26 (Number of young people involved), I2 (Number 
of recovered properties), I39 (Incentives for culture), and I38 (Number of social accounts). It is not only able to activate different communities (foreign residents and young people), but it also able to reuse properties and enhance the incentives for culture. The ability to improve the web communication is another relevant factor that has contributed to the success of the regeneration process.

The figure $4 \mathrm{c}$ shows the results of the GAIA Visual Analysis with the final ranking of the practices and the position of the indicators.

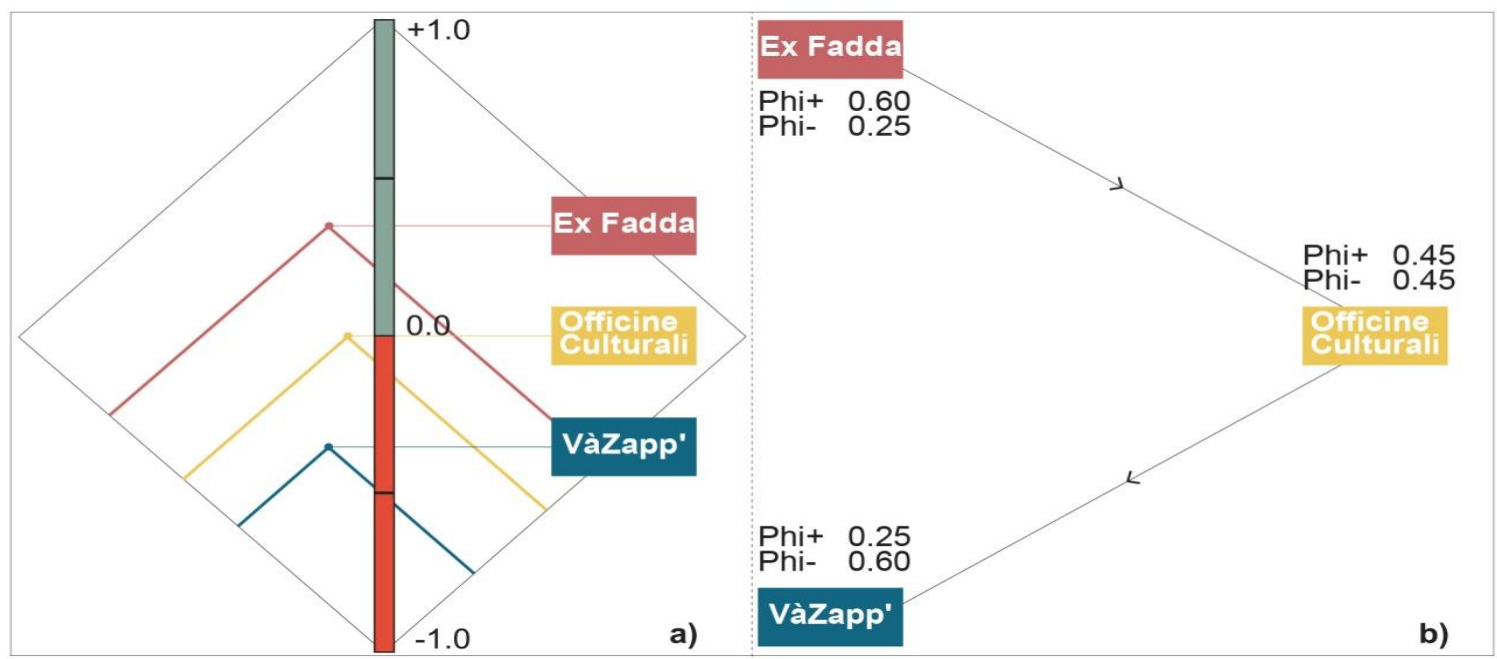

Figure 4: Evaluation of alternatives (a) PROMETHEE Diamond and (b) PROMETHEE Network (illustration: authors).

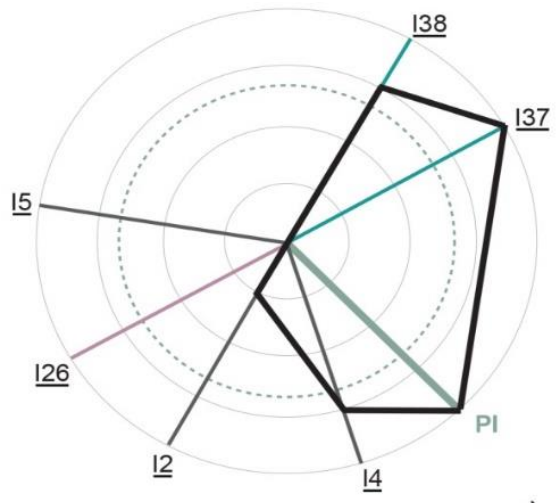

a)

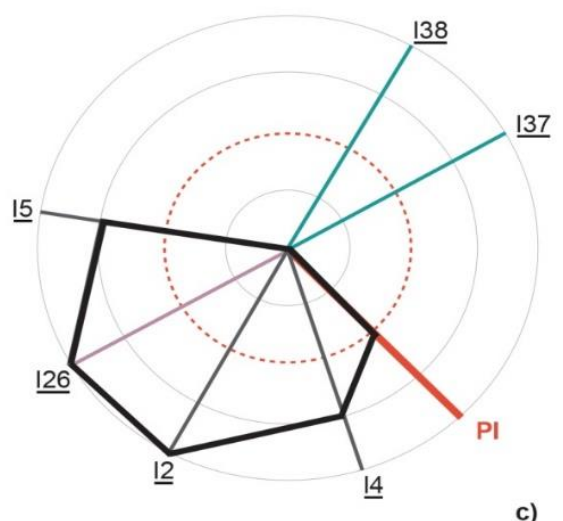

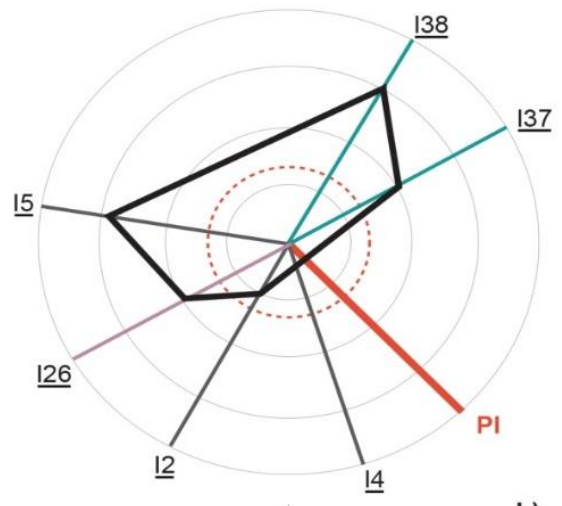

b)

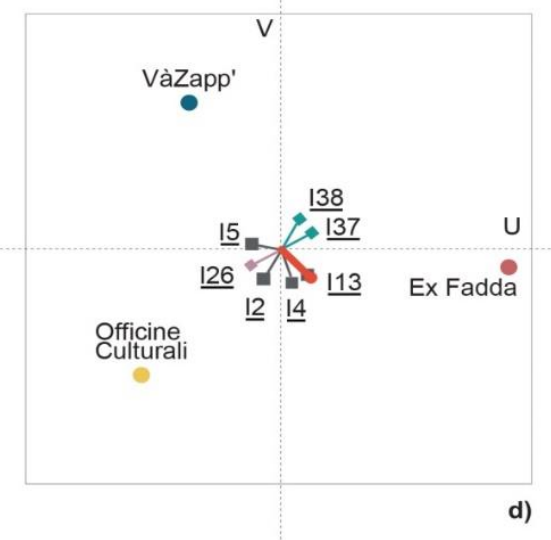

Figure 5: Evaluation of alternatives: GAIA Webs of a) Ex Fadda; b) VàZapp; c) Officine Culturali; and d) GAIA Visual Analysis (illustration: authors). 
The decision aid models used are focused on analysing the decision problem and providing the decision-maker with sound advice (Mareschal, 2013). For this reason, with the help of the Walking Weights sensitivity analysis, we compare the point of views of three decision makers in order to highlight the evaluation changes of different alternatives: the first hypothesis is without weights, while the second hypothesis is through the weights of criteria related to the local practices framework and one that considers the domain related to Enabling Environment (EE) to be more relevant, and the third hypothesis is consistent with The Cultural and Creative Cities Monitor weights, related to the European framework. In the Walking Weights, all the computations and windows contents are continuously adjusted and updated. It is an interactive tool used for modifying the weights in real time (Figure 6).

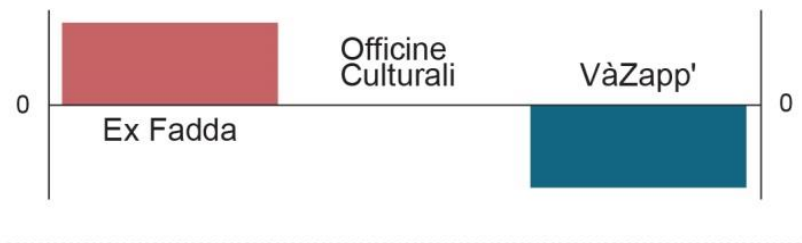

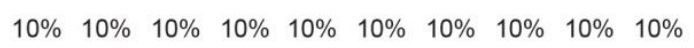

$\begin{array}{lllllllllll}12 & \underline{14} & \underline{15} & \underline{17} & \underline{18} & \underline{113} & \underline{122} & \underline{126} & \underline{137} & \underline{138} & \text { a) }\end{array}$

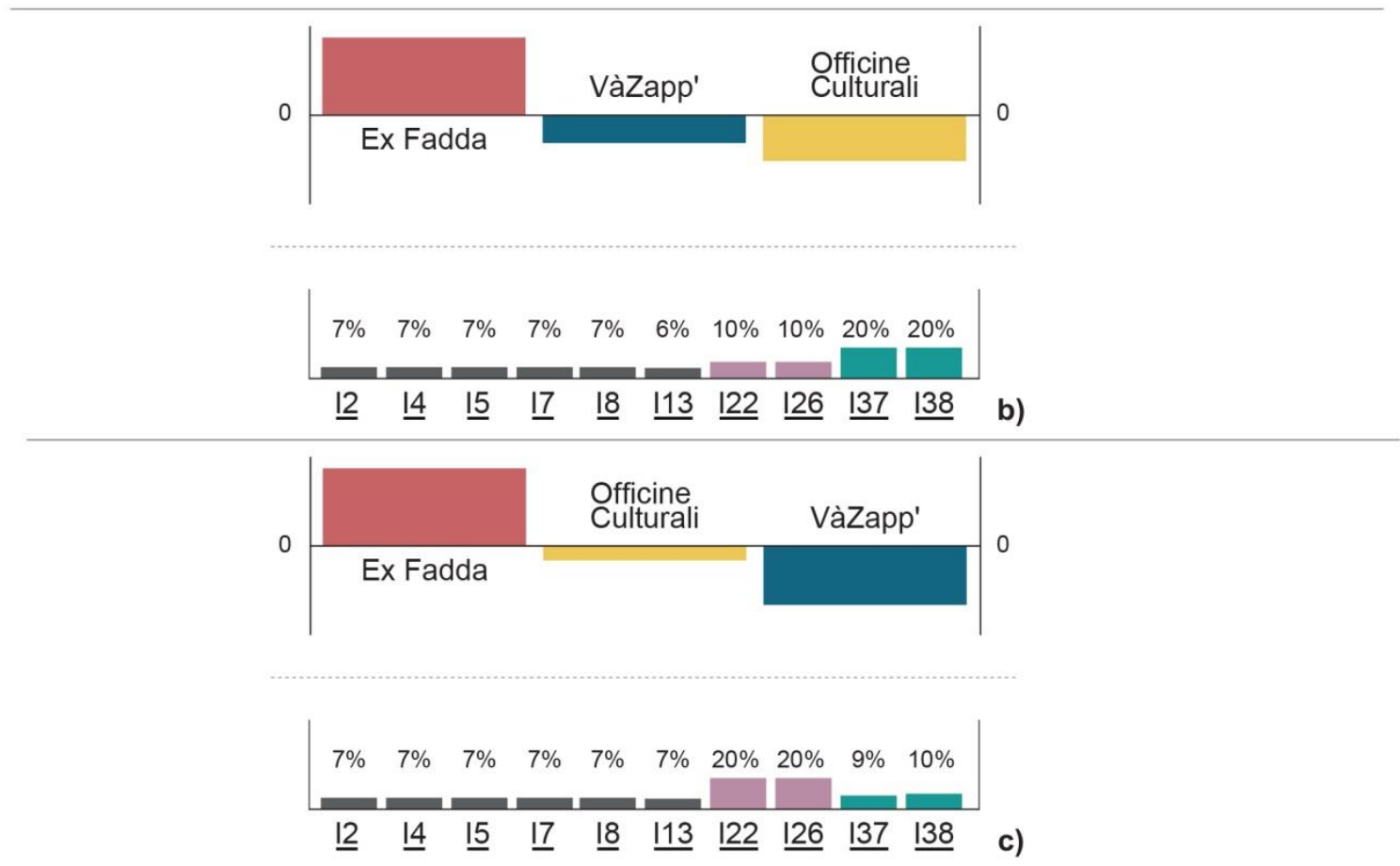

Figure 6: Sensitivity analysis - Walking weights for: a) Without weights; b) Practices' criteria weights; c) The Cultural and Creative Cities Monitor weights (illustration: authors).

The analysis of the data suggests that Ex Fadda is the most balanced practice in terms of activating culture-led urban regeneration. This is because it can insert new types of creative economy and welfare linked to the proximity for local-embedded development. Conversely, Officine Culturali and VàZapp' alternate in the second and third place. Reading these experiences highlights how culture can be a driver of development and enhancement based on local resources and identity and, on the other hand, based on 
participatory resources, such as communication technologies and innovative forms of cooperation among people and creative experts.

\section{Results and discussion}

The methodological approach has been enacted in six phases: literature review, evaluation framework, case studies selection, core set of indicators, ex-post evaluation of alternatives, and sensitivity analysis.

The literature analysis has indicated that culture-led regeneration is a strategic priority in current theories, policies, and practices. Indeed, culture, as an integrated and driving component, can make a difference in the processes of urban regeneration: renewing the image of the city and its neighbourhoods, fostering pride and a sense of belonging amongst its residents, attracting investment and tourism, improving the quality of life and social cohesion, enabling new job opportunities in the cultural and creative sectors, etc. The synergistic effect of culture-led regeneration depends, therefore, on how the process is able to create a shared and inclusive social representation, in which the various local communities can learn to expand their ability to interact, creating and sharing information and ideas to cooperate and compete together. The complex value of places (Fusco Girard \& Nijkamp, 1997; Cerreta, 2010) is generated through an interactive growth process and a governance model in which both the bottom-up and the top-down approach coexist, enabled by cultural experiences to which urban space is, at the same time, the social and the cultural arena.

The evaluation framework identifies three main domains, Cultural Vibrancy (CV), Creative Economy (CE), and Enabling Environment (EE), and the related dimensions, criteria, and indicators that are selected in order to develop the ex-post evaluations of practices results. The elaboration of the described decision tree combines the suggestions derived both from literature analysis and the characteristics of analysed experiences.

In the case studies selection phase, taking into account the research questions explored by the paper, we can underline that the local selected practices observed in their implementation process, and the results identify as main cultural resources the man-made capital, the human capital, the social capital, the local knowledge, and the traditions. The identification of the change opportunities enhances the specific and situated resources and activates a decision context that is able to optimize their mix in order to achieve local sustainable development goals.

Starting from the decision tree elaborated during the phase of elaboration framework, a core set of indicators has been identified in order to compare the three experiences considering the main common issues. The indicators used are expressed in quantitative units of measurement and allow the results to be described, taking into account information that is centred on the objective components of the evaluation. In a subsequent phase of the study, it is considered essential to develop appropriate indicators that allow the inclusion of subjective components, making explicit the points of view of the different types of actors involved in the decision-making process. In fact, structured assessment, combining both objective and subjective components, makes it possible to analyse practices, taking into account not only the results obtained, but also how they are perceived by the different actors in the decision-making process. The last two phases of 
the methodological approach, related to ex-post evaluation of alternatives and sensitivity analysis, help to understand that decision-making processes are incremental and adaptive, oriented to consolidate flexible and evolving networks of relationships, and are open to a constructive dialogue among the different actors involved.

The three different regeneration processes analysed identify new uses of the existing heritage that try to combine local traditional uses with innovative management models, additionally supported by new technologies. Users are not limited to those who frequent the spaces, but also to the wider virtual community that follows the activities on the network. The selected practices consider the need to build relationships (physical, social, economic) between different uses and see users as essential in order to trigger chains of multidimensional values. Each practice promotes a short chain process, implementing different declinations of the circular economy model, in which agriculture, art, training, research, tourism are the fields of experimentation of a new productive process. The direct participation in the process and the active involvement of the users allow producing new interests and stimulating new energies: new bonds are formed between the different decision-making actors, who recognize in collaboration and cooperation the concrete opportunity to improve their own wellbeing and that of community.

Building complex values networks is, at the same time, a challenge and a goal: the networks of values that are formed intertwine economic, social, cultural, and environmental values, with respect to which the direct interests of users are evident. The way in which communities are activated is often connected to the requests of certain subjects (individuals, groups, institutions, citizens) who recognize the need for change in contexts characterized by high potential. Individual and collective culture, expressed in strategy, actions, and behaviours, becomes the link that feeds itself and regenerates itself, supporting the transformation process and guiding the identification of suitable actions. The "creative communities", consisting of different skills, complementary and synergistic, develop decision-making processes oriented to conceive and test shared actions, generating complex productive networks among people, values, and space.

\section{Conclusions}

The components of new forms of local complex values in the regeneration processes, identified through an ex-post evaluation of some selected Italian practices, identify how decision-making processes, their articulation, and their activation have a significant impact on regeneration practices. This allows the identification of more appropriate actions for the regeneration of buildings and urban spaces to be taken. A determined role is played by the quantity and quality of social relations that trigger and allow the development of synergic and symbiotic processes. These processes are capable of supporting and feeding the different types of actions, continuously innovating the initial project through new ideas and resources (Zamagni et al., 2015). They highlight how the participation and active involvement of the various actors can generate different types of values, including the social use and economic value. Above all, they can create enabling environments that are characterized by the bonds that translate themselves into intrinsic values.

The positive externalities deriving from the bottom-up processes of valorization contribute to the regeneration of spaces and buildings, simultaneously producing 
employment and increasing the network of relationships in the local community. They contribute both to the economic development of the area and to the social and cultural development, providing services that public administrations can no longer support. This allows generated processes to be consistent with the principles of a circular economy, extracting residual value from existing spaces and promoting their reuse and possible upcycle. The bottom-up processes of enhancement progress are built over time. The priority in this area aims to research innovative regeneration tools that, on the one hand, define temporal solutions adapted to new uses and, on the other, guarantee reversible and economically sustainable interventions (Henneberry, 2017). The incremental evolution and temporariness of uses are two important issues that are capable of influencing the activation and development of regeneration processes. The practices analysed here point to the possibility of enhancing the public real estate assets and responding to a crucial challenge for both the historic centres and the suburbs. In addition, they highlight how activating projects of cultural and social innovation can generate new economic value in built heritage, promoting both economic development and urban regeneration.

Maria Cerreta, University of Naples Federico II, DiARC - Department of Architecture, Naples, Italy (maria.cerreta@unina.it)

Gaia Daldanise, IRISS of National Research Council, Naples, Italy (g.daldanise@iriss.cnr.it)

Sabrina Sposito, Leibniz Universität Hannover, Institute of Urban Design and Planning, Hannover, Germany (sposito@ staedtebau.uni-hannover.de)

\section{Acknowledgment}

Within the unitary work, Sabrina Sposito developed the first part (Section 1); Gaia Daldanise developed Section 4; Maria Cerreta developed Sections 5 and 6. All authors developed the methodological and data collection approach of the research in Section 2 and 3. The authors are very grateful to Marco Notarnicola for several datasets on Ex Fadda, and to Chiara Pirro for all of the information related to VàZapp'.

\section{References}

Bianchini, F. (1993) Remaking European cities: The role of cultural policies. In: Bianchini, F. \& Prkinson, M. (eds.) Cultural policy and urban regeneration: The West European experience, pp. 21-47. Manchester, Manchester University Press.

Behzadian, M., Kazemzadeh, R. B., Albadvi, A. \& Aghdasi, M. (2010) PROMETHEE: A comprehensive literature review on methodologies and applications. European Journal of Operational Research, 200(1), pp. 198-215. DOI: 10.1016/j.ejor.2009.01.021

Bertacchini, E. E., Bravo, G., Marrelli, M. \& Santagata, W. (eds.) (2012) Cultural commons: A new perspective on the production and evolution of cultures. Cheltenham, Edward Elgar Publishing. DOI: $10.4337 / 9781781000069$

Boschma, R. (2005) Proximity and innovation: A critical assessment. Regional Studies, 39(1), pp. 61-74. DOI: $10.1080 / 0034340052000320887$

Bosi, G. (2017) L'impresa culturale. Diritto ed economia delle comunità creative. Bologna, Il Mulino.

Brans, J. P. \& Mareschal, B. (1990) The PROMETHEE methods for MCDM; the PROMCALC, GAIA and BANKADVISER software. In: Bana e Costa, C. A. (ed.) Readings in multiple criteria decision aid, pp. 216-252. Heidelberg, Springer-Verlag Berlin. DOI: 10.1007/978-3-642-75935-2_10

Brans, J. P. (1982) Lingenierie de la decision. Elaboration d'instruments d'aide à la decision. Methode PROMETHEE. In: Nadeau, R. \& Landry, M. (eds.) L'aide à la decision: Nature, instruments et perspectives d'avenir, pp. 183-214. Quebec, Presses de Universite Laval.

Brenner, N. (ed.) (2014) Implosion/explosion: Towards a study of planetary urbanization. Berlin, Jovis. 
Brigato, M. V., Coscia, C., Curto, R. \& Fregonara, E. (2014) Valutazioni per strategie di sviluppo turistico sostenibile. Il caso del Bacino Metallifero dell'Iglesiente (ITA), Territorio, 69, pp. 1-11. DOI: 10.3280/TR2014-069018

Cerreta, M. (2010) Thinking through complex values. In: Cerreta, M., Concilio, G. \& Monno, V. (eds.) Making strategies in spatial planning. Knowledge and values, pp. 381-404. Dordrecht, The Netherlands, Springer. DOI: 10.1007/978-90-481-3106-8_21

Cerreta, M. \& Daldanise, G. (2017) Community Branding (Co-Bra): A collaborative decision making process for urban regeneration. In: Gervasi, O., Murgante, B., Misra, S., Borruso, G., Torre, C.M., Rocha, A. M. A. C., et al. (eds.) Computational science and its applications - ICCSA 2016. Lecture Notes in Computer Science, 10406, pp. 730-746. Cham, Springer International Publishing.

Cerreta, M., Panaro, S. \& Poli, G. (2016) A knowledge-based approach for the implementation of a SDSS in the Partenio Regional Park (Italy). In: Gervasi, O., Murgante, B., Misra, S., Rocha, A. M. A. C., Torre, C.M., Taniar, D., et al. (eds.) Computational science and its applications - ICCSA 2016. Lecture Notes in Computer Science, 9789, pp. 111-124. Cham, Springer International Publishing. DOI: 10.1007/978-3-319-42089-9_8

CHCfE (2015) Cultural heritage counts for Europe. Available at: http://blogs.encatc.org/culturalheritagecountsforeurope/outcomes/ (accessed 3 May 2017).

Cinquemani, T. (2016) I giovani agricoltori si mettono in rete con VàZapp'. Available at: http://agronotizie.imagelinenetwork.com 1 (accessed 05 Jul. 2017).

Community places (2014) Community planning. Available at: www.communityplanningtoolkit.org (accessed: 07 May 2017).

Corboz, A. (1998) L'urbanistica del XX secolo: un bilancio (1992). In: Viganò, P. (ed.) Ordine sparso, saggi sull'arte, il metodo, la città e il territorio, pp. 219-227. Milano, Franco Angeli.

Corner, J. (2006) Terra fluxus. In: Waldheim, C. (ed.) The landscape urbanism reader, pp. 21-33. New York, Princeton Architectural Press.

Esposito de Vita, G. \& Ragozino, S. (2014) Natural commercial centers: Regeneration opportunities and urban challenges. Advanced Engineering Forum, 11, pp. 392-401. DOI: 10.4028/www.scientific.net/AEF.11.392

European Commission (2017) The cultural and creative cities monitor. Research report. Available at: https://ec.europa.eu/jrc/en/publication/eur-scientific-and-technical-research-reports/cultural-andcreative-cities-monitor-2017-edition (accessed 06 Jul. 2017).

Evans, G. \& Shaw, P. (2004) The contribution of culture to regeneration in the UK: A review of evidence. A report to the Department for Culture, Media and Sport. London, LondonMet.

Fabris, G. (2008) Societing. Milano, Egea.

Florida, R. L. (2003). L'ascesa della nuova classe creativa: stile di vita, valori e professioni. Milano, Mondadori.

Forester, J. (1997) Beyond dialogue to transformative learning: How deliberative rituals encourage political judgment in community planning processes. Evaluating theory-practice and urban-rural interplay in planning, 37, pp. 81-103. DOI: 10.1007/978-94-011-5462-8_7

Fusco Girard, L. (2010) Sustainability, creativity, resilience: Toward new development strategies of port areas through evaluation processes. International Journal of Sustainable Development, 13(1), pp. 161-184. DOI: 10.1504/IJSD.2010.035106

Fusco Girard, L. \& Nijkamp, P. (1997) Le valutazioni per lo sviluppo sostenibile della città e del territorio. Milano, Franco Angeli.

Gasparrini, C. \& Terracciano, A. (eds.) (2016) Drosscity. Metabolismo, resilienza e progetto di riciclo dei drosscape. Trento, ListLAB Edition.

Garcìa, B. (2004) Cultural policy and urban regeneration in Western European cities: Lessons from experience, prospects for the future. Local Economy, 19(4), pp. 312-326. DOI: $10.1080 / 0269094042000286828$

Garcì, B. (2005) Deconstructing the city of culture: The long-term cultural legacies of Glasgow 1990. Urban Studies, 42(5-6), pp. 841-868. DOI: 10.1080/00420980500107532

Henneberry, J. (ed.) (2017) Transience and permanence in urban development. Chichester, John Wiley \& Sons. DOI: $10.1002 / 9781119055662$

Internet 1: http://vazapp.it (accessed 2 Apr. 2017).

Internet 2: http://www.exfadda.it (accessed 3 Apr. 2017).

Internet 3: http://www.officineculturali.net (accessed 4 Apr. 2017).

Ishizaka, A. \& Nemery, P. (2013) Multi-criteria decision analysis: methods and software. Chichester, John Wiley \& Sons. DOI: 10.1002/9781118644898

La Redazione (2014) Esplora il significato del termine: ExFadda, l'officina che crea il futuro. Available at: http://nuvola.corriere.it/2014/06/16/exfadda-il-laboratorio-che-crea-il-futuro (accessed 20 Jun. 
2017).

Lefebvre, H. (1970) Reflections on the politics of space. In: Brenner, N. \& Elden, S. (eds.) (2009) Lefebvre, Henri, 1901-1991. State, space, world: selected essays / Henri Lefebvre. Minneapolis, University of Minnesota Press.

Madanipour, A. (2011) Knowledge economy and the city: Spaces of knowledge. New York, Routledge.

Manzini, E. (2017) La produzione sociale di luoghi in un mondo connesso. In: Venturi, P. \& Rago, S. (eds.) Da Spazi a Luoghi. Proposte per una nuova ecologia dello sviluppo, pp. 101-108. Forli, AICCON.

Mareschal, B. (2013) Visual PROMETHEE 1.4 Manual. Available at: www.Promethee-Gaia.Net (accessed: 20 Jun. 2017).

McCarthy, J. (1998) Dublin's Temple Bar-A case study of culture-led regeneration. European Planning Studies, 6(3), pp. 271-281. DOI: 10.1080/09654319808720461

McCarthy, J. (2006) Regeneration of cultural quarters: Public art for place image or place identity? Journal of Urban Design, 11(2), pp. 243-262. DOI: 10.1080/13574800600644118

McHarg, I. (1969) Design with nature. New York, Natural History Press.

McHarg, I. (2007) The theory of creative fitting. In: Margulis, L., Corner, J., \& Hawthorne, B. (eds.) Ian McHarg: Conversations with students. Dwelling in nature, pp. 20-61. New York, Princeton Architectural Press.

Micelli, E. (2009) Modelli ibridi di partnership pubblico-privato nei progetti urbani, Scienze Regionali, 8(2), pp.97-112.

Miles, S. \& Paddison, R. (2005) Introduction: The rise and rise of culture-led urban regeneration. Urban Studies, 42(5-6), pp. 833-839. DOI: 10.1080/00420980500107508

Munda, G. (1993) Multiple-criteria decision aid: Some epistemological considerations. Journal of MultiCriteria Decision Analysis, 2(1), pp. 41-55. DOI: 10.1002/mcda.4020020106

Napolitano, P. (2016) The socio-economic impact of the cultural heritage on the communities. Available at: http://www.digicult.it/it/news/the-socio-economic-impact-of-the-cultural-heritage-on-thecommunities/ (accessed 10 Apr. 2017).

Neuman, M. (1992) Wasting away by Kevin Lynch and The production of space by Henri Lefebvre. Berkeley Planning Journal, 7(1), pp.157 -165.

OECD (2002) No.6: Glossary of key terms in evaluation and results based management. Paris.

Olsson, N. O. E., Krane, H. P., Rolstadås, A. \& Veiseth, M. (2010) Influence of reference points in ex post evaluations of rail infrastructure projects. Transport Policy, 17(4), pp. 251-258. DOI: 10.1016/j.tranpol.2010.01.008

Pirlot, M. (1997) A common framework for describing some outranking methods. Journal of Multi-Criteria Decision Analysis, 6, pp. 86-92. DOI: 10.1002/(SICI)1099-1360(199703)6:2<86::AIDMCDA145>3.0.CO;2-D

Proctor, W. \& Drechsler, M. (2006) Deliberative multicriteria evaluation. Environment and Planning C: Government and Policy, 24(2), pp. 169-190. DOI: 10.1068/c22s

Roy, B. (1985) Méthodologie multicritère d'aide à la décision. Paris, Economica.

Sacco, P., Ferilli, G. \& Blessi, G. T. (2014) Understanding culture-led local development: A critique of alternative theoretical explanations. Urban Studies, 51(13), pp. 2806-2821. DOI: 10.1177/0042098013512876

Sacco, P. L. \& Pedrini, S. (2003) Il distretto culturale: mito o opportunità. Il Risparmio, 51(3), pp. 101155.

Samset, K. (2003) Project evaluation: Making investments succeed. Trondheim, TapirAcademic Press.

Sassen, S. (2011) Cities in a world economy. London, Sage Publications.

Scott, A. J. (2000) The cultural economy of cities: Essays on the geography of image-producing industries. London, Sage Publications.

Secchi, B. (2000) Prima lezione di urbanistica. Bari, Laterza.

Solima, L. (2005) L'impresa culturale: processi e strumenti di gestione. Roma, Carocci.

Sposito, S. (2016) Strategie e tecniche di "drossmapping": applicazioni nella cittá Domizio-Flegrea. In: Gasparrini, C. \& Terracciano, A. (eds.) (2016). Drosscity. Metabolismo, resilienza e progetto di riciclo dei drosscape, pp. 105-113. Trento-Barcellona, ListLAB Edition.

Torre, C.M., Attardi, R. \& Sannicandro, V. (2016) Integrating financial analysis and decision theory for the evaluation of alternative reuse scenarios of historical buildings. In: Gervasi, O., Murgante, B., Misra, S., Rocha, A. M. A. C., Torre, C.M., Taniar, D., et al. (eds). Computational science and its applications - ICCSA 2016. Lecture Notes in Computer Science, 9789, pp. 177-190. Cham, Springer. DOI: 10.1007/978-3-319-42089-9_13

Ufficio Studi Federculture (2013) Le industrie culturali e creative in Italia. Research report. Available at: monitoraggioprogetti.formez.it (accessed: 05 May 2017).

Unioncamere \& Fondazione Symbola (2017) Io sono cultura - 2017. L'Italia della qualità e della 
bellezza sfida la crisi. Quaderni di Symbola. Available at:

http://www.symbola.net/assets/files/IoSonoCultura_2017_DEF_1498646352.pdf (accessed 10 July 2017).

Vincke, J.P. \& Brans, Ph. (1985) A preference ranking organization method. The PROMETHEE method for MCDM. Management Science, 31, pp. 641-656.

Vincke, P. (1992) Multicriteria decision-aid. Chichester, John Wiley \& Sons.

Zamagni, S. (2017) I luoghi dell'economia civile per lo sviluppo sostenibile. In: Venturi, P., Rago, S. (eds.) Da spazi a luoghi. Proposte per una nuova ecologia dello sviluppo, pp. 11-20. Forli, AICCON.

Zamagni, S., Venturi, P. \& Rago, S. (2015) Valutare l'impatto sociale. La questione della misurazione nelle imprese sociali. Impresa sociale, 6, pp. 77-97. 